\title{
SIMILARITY OF THE EUROPEAN UNION COUNTRIES IN TERMS OF GRADUATES' FIELDS OF EDUCATION
}

\author{
JAN POLCYN, ${ }^{1}$ ANNA TURCZAK ${ }^{2}$ \\ ${ }^{1}$ Stanisław Staszic University of Applied Sciences in Piła, POLAND \\ e-mail: Jan.Polcyn@pwsz.pila.pl \\ 2 The West Pomeranian Business School in Szczecin, POLAND \\ e-mail: aturczak@zpsb.pl
}

RECEIVED
ACCEPTED
JEL
CLASSIFICATION

KEYWORDS

ABSTRACT
20 July 2017

15 December 2017

$\mathrm{C} 46, \mathrm{I21}, \mathrm{I23}$

graduates' field of education, the European Union, distribution, dendrite method

The purpose of the paper is to divide the European Union countries into groups of most similar distributions of graduates' fields of education. The study covers three education levels - bachelor's, master's, doctoral - and ten different fields. As a measure of the degree of similarity of distributions $D$ statistic was used, which is the maximum absolute value of the difference between two cumulative distribution functions. Data from 2015 were used for computations. On the basis of the values of the $D$ statistic calculated for each of the pairs of distributions the countries were divided into relatively uniform classes. The implemented procedure enabled to distinguish one compact cluster of countries in the case of the bachelor's level of education, two unlike sets in the case of the master's level and one relatively homogenous group in the case of the doctoral level.

\section{Introduction}

Knowledge is readily recognized as one of the main drivers of economic development, and countries which are able to make best use of knowledge are more successful on the global market (Aubert, Reiffers, 2003). As can be seen from the overview of empirically based studies, it is clear that the overall economic performance of modern 
economies is increasingly and more directly based upon their knowledge stock and their learning capabilities (Neef et al., 2011).

First and foremost, the twenty-first century is characterised by constant change. Moreover, we are living in an age of continuous innovation. Curiosity and creativity are the crucial motivating forces for all innovations. In the contemporary world, a new paradigm of multidimensional development is emerging that embracing economic, cultural, technological and social aspects at both the macro and micro levels. Central to the paradigm is the fact that creativity and access to information are more and more recognised as powerful engines driving economic growth and promoting development in all other dimensions. Creativity in this context refers to the formulation of new ideas and to the application of these ideas to produce functional creations, scientific inventions and technological innovations, as well as original works of art and cultural products. The best outcomes come from creativity in management, arts, science \& technology combined together, and an eclectic mix of them is vital for multidimensional development stimulated by innovations (United Nations, 2008, pp. 4-9).

The role of education in the knowledge-based economy is outstanding (Cunningham, Jaaniste, 2010). What is very important, as D. Kirk (2010) argues, the transmission of knowledge through formal education is a good foundation for building a creative economy. It is also worth adding what D.P. Baker (2012, p. 97) has aptly noted: formal education not only transforms individuals, it reconstitutes entire societies. However, learning is not merely the precondition for innovation, technological progress, and the over-hyped rise of an information economy; it is also the precondition for imagination, civic courage, and collective struggles that expand and deepen the process of democratisation.

As the capacity of people to work creatively in the context of sustained innovation is emerging as a central feature of the economy today, higher education institutions must be in some measure estuaries in support of innovation (Araya, 2010, p. 22). Unfortunately, most who have commented on the university's role in the economy believe the key lies in increasing its ability to transfer research to industry, generate new inventions and patents, and spin off its technology in the form of start-up companies. As such, there has been a movement around the world to make universities "engines of innovation" and to enhance their ability to commercialize their research (Feller, 1990; David, 1997). Universities have largely bought into this view because it makes their work more economically relevant and as a way to bolster their budgets. However, this view misses the deeper and more fundamental contributions made by the higher education institutions to innovation, the larger economy, and society as a whole (Florida et al., 2010 , p. 45). Technology is, indeed, very important, but the role of the universities encompasses much more than just the generation of technology.

\section{Objective, research tasks and methodology}

It is easy to find that the twenty-first century is the time of educational expansion in the European Union countries, especially the expansion of mass higher education. Additionally, there is a great diversity of education fields in each Member State at all three levels of higher education. Hence, the identification of the EU countries that are characterized by very similar graduates' field of education distributions, and those countries which differ from others in terms of the distribution of the discussed variable, has become the objective of this paper. The objective was achieved by carrying out the following research tasks: 1) selecting a statistic that allows for making comparisons 
of distributions; 2) determining the values of this statistic for each pair of distributions; 3 ) dividing the analysed countries into groups with similar field of education distributions.

The study was accomplished separately for the bachelor's, master's and doctoral level of education and covered the following fields: 1. education, 2. arts and humanities, 3. social sciences, journalism and information, 4. business, administration and law, 5. natural sciences, mathematics and statistics, 6. information and communication technologies, 7. engineering, manufacturing and construction, 8. agriculture, forestry, fishery and veterinary, 9. health and welfare, 10. services. All calculations were carried out based on Eurostat database. Data for 2015 were used.

In the study conducted in this paper the authors have used an original conglomerate of statistical tools, namely, the maximum absolute value of the difference between cumulative distribution functions and the dendrite method. The dendrite method is admittedly well known method of classification, but in this study it has been applied in an innovative way.

The considered qualitative variable is the field of education. The cumulative distribution function $F$ fully defines the distribution of the variable in a given population (Turczak, Zwiech, 2016). Hence, the comparison of distributions of the variable in two populations can be reduced to the comparison of values of cumulative distribution functions in these populations, and if two populations have the same distribution, the values of their cumulative distribution functions have to be identical in all points (Razali, Wah, 2011).

Let the first population contain $n_{1}$ elements, and the other $-n_{2}$ elements. Then $F_{1}$ and $F_{2}$ stand for cumulative distribution functions regarding the first and the second population, respectively. The scale of differences between the values of these functions is the subject of the further analysis. The values of the cumulative distribution functions had to be calculated for each $i$-th category of the variable according to the formulas (Turczak, Zwiech, 2015, p. 104):

$$
F_{1, i}=n_{1 \text { cum }, i} / n_{1, i} ; \quad F_{2, i}=n_{2 \text { cum }, i} / n_{2, i}
$$

In the next step for each $i$-th category the absolute value of the difference between the cumulative distribution functions was determined and the largest one - labelled as $D_{1,2}$ - was indicated. Thus, the measure $D_{1,2}$ was defined as (Arnold, Emerson, 2011, p. 34):

$$
D_{1,2}=\max _{i}\left|F_{1, i}-F_{2, i}\right| \cdot
$$

Thanks to the classification procedure the set of twenty eight countries can be divided into subsets that are relatively uniform with respect to the adopted criterion. Such a division is desirable, in which the value of $D$ statistic calculated for any pair of countries belonging to the same group is less than the value of the statistic for any pair of countries belonging to different groups. The classification procedure was carried out in the following stages:

Stage 1. On the basis of the values of $D$ statistic for each country the country most similar was found. Then the dendrite was built composed of vertices and lines. The construction of the dendrite was started by joining each country with the most similar one. As a result of such a joining procedure a graph consisting of first order clusters was created in which countries were connected to one another by lines in a direct or indirect way. More than one first order cluster was obtained and therefore it was necessary to carry out the second stage.

Stage 2. At that stage for each first order cluster the most similar one had to be found. As the value of the $D$ statistic referring to a pair of clusters, the minimum value of this statistic calculated for countries belonging to 
these two clusters was assumed. Consequently, by joining each first order cluster with the most similar one, the second order clusters were formed. The described procedure was repeated until all clusters were connected.

Stage 3. The number of groups the dendrite should be divided into can be determined by comparing the lengths of its lines with the threshold value $\hat{D}$. As the threshold value $\hat{D}$ the arithmetic mean of the $D$ statistics calculated for all the 378 pairs of countries can be assumed. The pairs of countries for which the inequality $D>\hat{D}$ is satisfied can be recognized as similar. Conversely, those pairs of countries for which the relation $D \geq \hat{D}$ is fulfilled are considered to be dissimilar and therefore cannot be placed in the same group. Finally, the lines corresponding to distances exceeding the $\hat{D}$ value have to be removed from the dendrite.

\section{Countries similar as regards the distribution of education fields at the bachelor's level}

The completion of the first and the second stage of dendrite method led to formation of the connected graph presented in Figure 1.

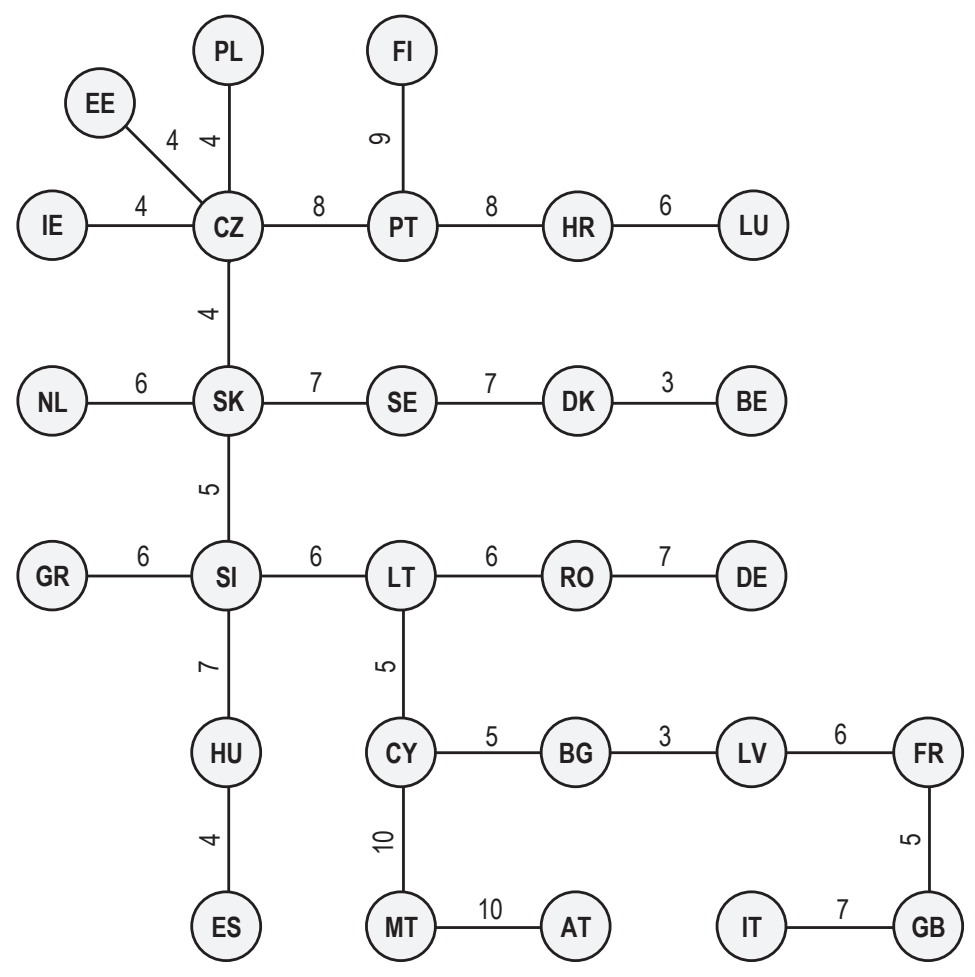

Figure 1. The dendrite constructed for the bachelor's level of education (distances in p.p.)

Source: own compilation based on Eurostat database (access: 10.07.2017).

The threshold value is 14.7 p.p. All distances in Figure 1 are smaller than 14.7 p.p. It means it is not necessary to delete any lines in the graph - all the EU countries constitute a relatively homogeneous set. 


\section{Countries similar as regards the distribution of education fields at the master's level}

Now the task is to examine which of the Member States have alike distributions concerning the fields of master's level education. Based on the $D$ values the graph in Figure 2 was drawn.

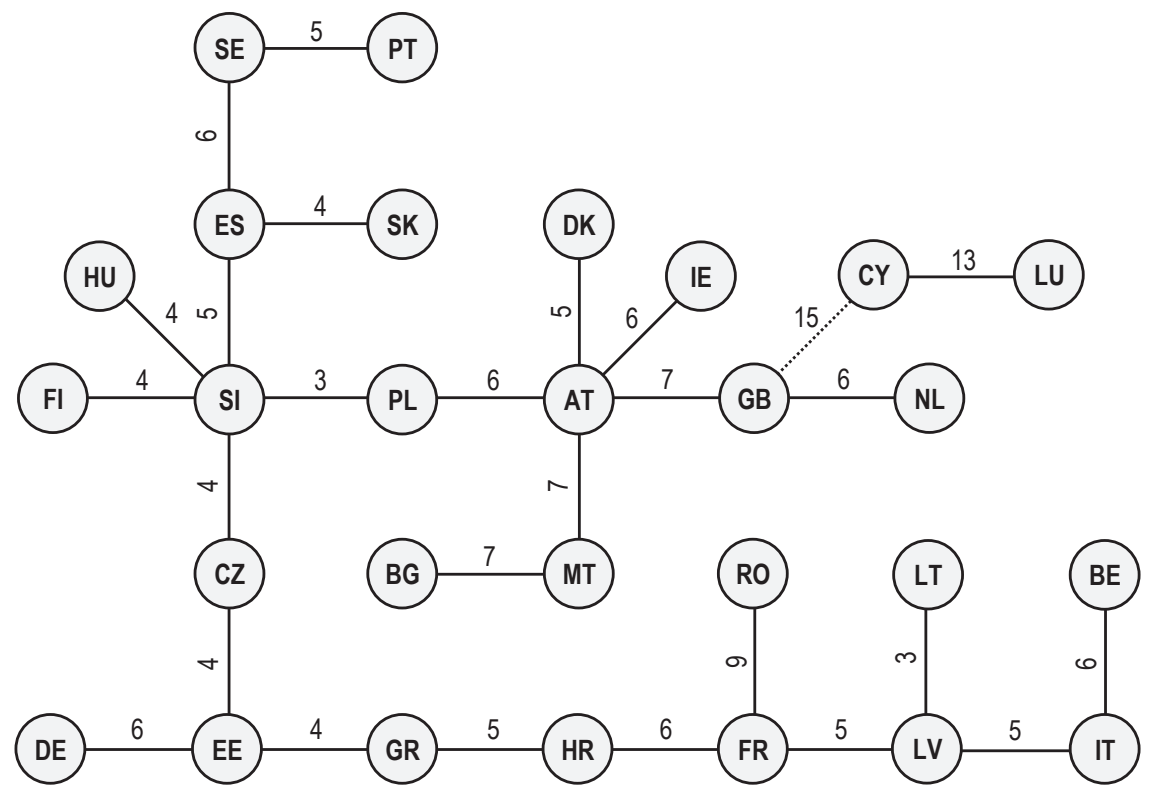

Figure 2. The dendrite constructed for the master's level of education (distances in p.p.)

Source: as in Figure 1.

The threshold value amounts to 13.9 p.p. It is easy to notice that only one distance in Figure 2 is greater than 13.9, namely that of length equal to 15 p.p. It means the line corresponding to this value has to be eliminated from the connected dendrite (in Figure 2 this line in question is depicted as the dotted one). Thus, the division results in the creation of one 2-elements group and one 26 -elements group. 


\section{Countries similar as regards the distribution of education fields at the doctoral level}

The connected dendrite is illustrated in Figure 3.

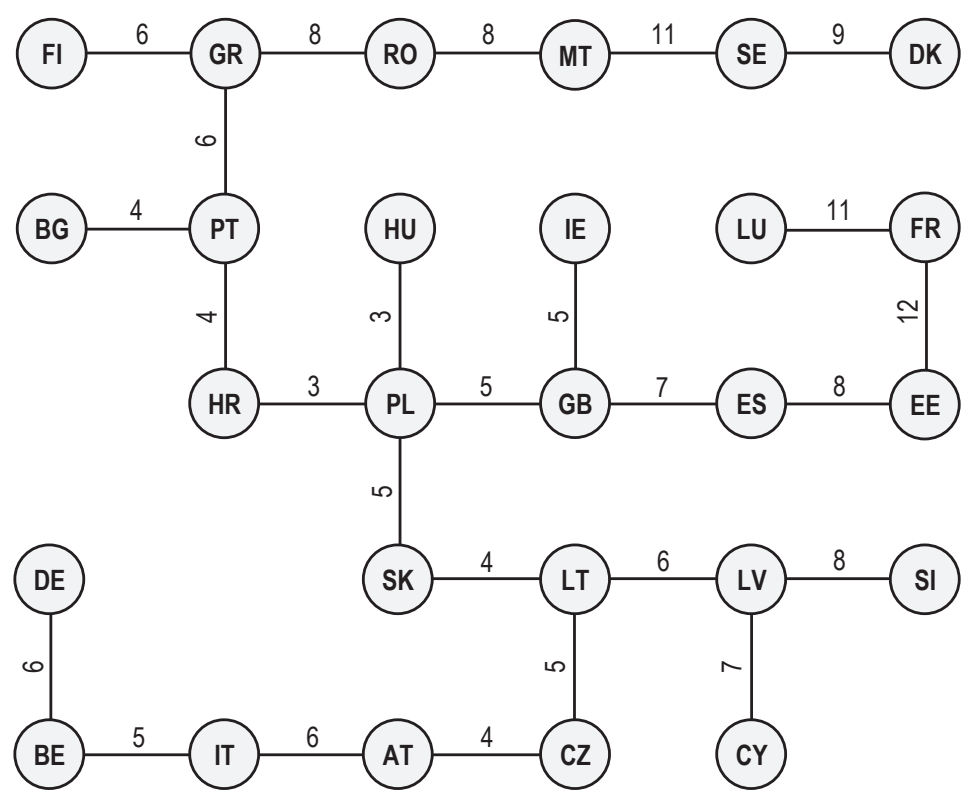

Figure 3. The dendrite constructed for the doctoral level of education ${ }^{1}$ (distances in p.p.)

Source: as in Figure 1.

The threshold value is 15.6 p.p. Due to the fact that all distances in Figure 3 are shorter than 15.6 p.p., there is no need to remove any lines from the graph. Hence, it can be assumed that the EU countries covered by the study form a compact collection and should not be split into smaller groups.

\section{Conclusions}

Knowledge is the key driver of economic growth and the major determinant of competitiveness on the globalized market (Corno et al., 2000). D. Rooney (2010) has rightly stated that the comparative advantage is increasingly based on the creative use of knowledge. In fact, innovations are produced by human imagination and, as such, are the main factor of multidimensional development of modern economies (Gürüz, 2011).

The defining characteristic of the creative economy is transdisciplinarity: the interaction, translation, and synthesis of knowledge between and among technical, cultural, social and other disciplines, and also between different subdisciplines within each. According to G. Hearn and R. Bridgstock (2010) innovations that reach

\footnotetext{
${ }^{1}$ Netherlands has been excluded from this study because the data concerning fields of doctoral education in Netherlands have been not recorded.
} 
the market are rarely the products of single disciplines, but rather they involve compound multidisciplinary knowledge regimes. Indeed, modern corporations, for instance, may be most distinguished by their ability to bring together composite knowledge (e.g., scientific, marketing, and legal one). It is extremely important to realize that commercialisation depends on "whole product value propositions", not just basic research in one or two disciplines. Creativity is found across the technological, economic, and artistic domains, in diverse forms such as patents and designs, and also in the areas of entrepreneurship and business administration. "No intellectual domain or economic sector has a monopoly on creativity" (Mitchell et al., 2003, p. 18). Even the classical economists emphasized many times that the wealth of nations is not only the derivative of effective operating on the market, but also depends on how individual skills, talents, and motivations are utilised (Leśniewska, Pluta, 2011). There is no doubt that since the paradigm of creative economy so strongly promotes diversity - the natural sciences \& engineering, arts \& humanities, economics \& sociology and all other fields should be involved in forming and developing the creative economy.

The role of the higher education institutions in the process of transition of today's economies into the creative ones is invaluable. However, it has to be noted that universities' role goes far beyond just technology - they play a significant role also across the other axes of multidimensional development.

There has been a huge expansion of higher education in the European Union countries, especially over the last several years. Furthermore, there is a great variety of fields of study in all the Member States. Hence, the aim of the paper was to determine the degree of similarity between the EU countries in terms of the distribution concerning graduates' fields of education and to single out countries alike in that respect. In order to accomplish this task, for each pair of the Member States the maximum absolute value of the difference between cumulative distribution functions was computed and then the dendrite method was employed.

When it comes to the bachelor's and doctorial level of education, all the European Union countries are quite similar in respect of graduates' fields of education. However, in the case of the master's level the Member States have to be split into two clusters of alike distributions. The first class comprises Cyprus and Luxembourg, and the second one consists of the other twenty six EU countries. Table 1 presents information on the mean distributions in each of the specified groups.

Table 1. Structural patterns in the isolated groups (\%)

\begin{tabular}{|c|c|c|c|c|}
\hline \multirow{3}{*}{ Field of education } & \multicolumn{4}{|c|}{ Level of higher education } \\
\hline & \multirow{2}{*}{$\begin{array}{c}\text { bachelor's } \\
\text { all (28) }\end{array}$} & \multicolumn{2}{|c|}{ master's } & \multirow{2}{*}{$\begin{array}{c}\text { doctoral } \\
\text { all (27) }\end{array}$} \\
\hline & & $\{C Y, L U\}$ & other (26) & \\
\hline Education & 9.3 & 30.7 & 10.4 & 3.0 \\
\hline Arts and humanities & 12.6 & 5.5 & 9.7 & 12.2 \\
\hline Social sciences, journalism and information & 11.1 & 4.8 & 10.7 & 8.6 \\
\hline Business, administration and law & 22.3 & 41.1 & 26.5 & 8.1 \\
\hline Natural sciences, mathematics and statistics & 7.6 & 2.6 & 7.2 & 28.0 \\
\hline Information and communication technologies & 3.9 & 2.7 & 3.0 & 4.3 \\
\hline Engineering, manufacturing and construction & 14.0 & 6.3 & 15.0 & 15.0 \\
\hline Agriculture, forestry, fishery and veterinary & 1.6 & 0.4 & 1.6 & 2.9 \\
\hline Health and welfare & 13.5 & 4.8 & 13.6 & 17.1 \\
\hline Services & 4.0 & 1.1 & 2.2 & 0.7 \\
\hline Total & 100.0 & 100.0 & 100.0 & 100.0 \\
\hline
\end{tabular}

Source: as in Figure 1. 
Here are the characteristic features of the defined groups:

1. At the bachelor's level the most popular is 'business, administration and law', wherein $15.9 \%$ of people have graduated in 'business and administration', 3.7\% - in 'law', and 2.6\% - in 'inter-disciplinary programmes'.

2. In the case of Cyprus and Luxembourg, the master's degree graduates most often have finished 'business, administration and law': 37.4\% - 'business and administration', 3.1\% - 'law', and 0.5\% - 'inter-disciplinary programmes'. What is also specific for these two small countries, as many as $30.7 \%$ of students have graduated in 'education' (mainly 'teacher training' $-25.2 \%$ ).

3. In the set of remaining twenty six EU countries, the share of 'business and administration' graduates in the total number of master's level graduates is $17.8 \%$, the share of 'law' $-7.0 \%$, and the share of 'interdisciplinary programmes' $-1.8 \%$.

4. People who have been studying at the doctoral level most often have completed the 'natural sciences, mathematics and statistics' field ( $28.0 \%$ in total), in particular: 'physical sciences' $-12.9 \%$, and 'biological and related sciences' $-9.8 \%$.

In conclusion, it is worth emphasizing that present students have to be prepared to tackle not only the known, but also the unknown problems they will face. That is why it is so important to foster creativity in the 21 st century higher education. The role of modern education should be to inspire curiosity, to create an environment where creativity can bloom, to encourage students to be more involved in learning, to allow them to discover new things and to develop their individual skills. This is because the creative economies need to be based on people's use of their creative imagination.

\section{References}

Araya, D. (2010). Educational policy in the creative economy. In: D. Araya, M.A. Peters (eds.), Education in the creative economy. Knowledge and learning in the age of innovation (pp. 3-28). New York: Peter Lang Publishing.

Arnold, T.B., Emerson, J.W. (2011). Nonparametric goodness-of-fit tests for discrete null distributions. The R Journal, 2 (3), 34-39.

Aubert, J., Reiffers, J. (2003). Knowledge economies in the Middle East and North Africa: Toward new development strategies. Washington: The World Bank.

Baker, D.P. (2012). The educational transformation of work. A synthesis. In: H. Lauder, M. Young, H. Daniels, M. Balarin, J. Lowe (eds.), Educating for the knowledge economy? Critical perspectives (pp. 97-113). New York: Routledge - Taylor \& Francis Group.

Corno, F., Reinmoeller, P., Nonaka, I. (2000). Knowledge creation within industrial systems. Journal of Management and Governance, 3 (4), 379-394.

Cunningham, S., Jaaniste, L. (2010). The policy journey toward education for the creative economy. In: D. Araya, M.A. Peters (eds.), Education in the creative economy. Knowledge and learning in the age of innovation (pp. 29-44). New York: Peter Lang Publishing.

David, P. (1997). The knowledge factor: A survey of universities. The Economist, 4 (October).

Feller, I. (1990). Universities as engines of R\&D-based economic growth: They think they can. Research Policy, 4 (19), 335-348.

Florida, R., Knudsen, B., Stolarick, K. (2010). The university and the creative economy. In: D. Araya, M.A. Peters (eds.), Education in the creative economy. Knowledge and learning in the age of innovation (pp. 45-76). New York: Peter Lang Publishing.

Gürüz, K. (2011). Higher education and international student mobility in the global knowledge economy. New York: State University of New York Press.

Hearn, G., Bridgstock, R. (2010). Education for the creative economy: innovation, transdisciplinarity and networks. In: D. Araya, M.A. Peters (eds.), Education in the creative economy. Knowledge and learning in the age of innovation (pp. 93-115). New York: Peter Lang Publishing.

Kirk, D. (2010). The "knowledge society" in the Middle East. In: D. Obst, D. Kirk (eds.), Innovation through education: Building the knowledge economy in the Middle East (pp. 1-6). New York: The Institute of International Education. 
Leśniewska G., Pluta A. (2011). Oczekiwania rynku pracy a zainteresowania i preferencje zawodowe młodzieży. In: Cz. Plewka, H. Bednarczyk (eds.), Człowiek - Obywatel - Pracownik na rynku pracy (pp. 107-120). Szczecin: WSH TWP.

Mitchell, W., Inouye, A., Blumenthal, M. (2003). Beyond productivity: Information technology, innovation, and creativity. Washington: The National Academies Press.

Neef, D., Siesfeld, A., Cefola, J. (2011). The economic impact of knowledge. New York: Routledge - Taylor \& Francis Group.

Razali, N.M., Wah, Y.B. (2011). Power comparisons of Shapiro-Wilk, Kolmogorov-Smirnov, Lilliefors and Anderson-Darling tests. Journal of Statistical Modeling and Analytics, 1 (2), 21-33.

Rooney, D. (2010). Creatively wise education in a knowledge economy. In: D. Araya, M.A. Peters (eds.), Education in the creative economy. Knowledge and learning in the age of innovation (pp. 179-199). New York: Peter Lang Publishing.

Turczak, A., Zwiech, P. (2015). Podobieństwo województw w Polsce pod względem rozkładu wydatków ich mieszkańców. Ekonomia XXI Wieku, 3 (7), 100-112.

Turczak, A., Zwiech, P. (2016). Porównanie województw w Polsce na podstawie rozkładu dochodu rozporządzalnego per capita. Optimum. Studia Ekonomiczne, 3 (81), 131-147.

United Nations (2008). Creative economy. The challenge of assessing the creative economy: Towards informed policy-making. Retrieved from: http://www.unctad.org (15.07.2017).

Cite this article aS: Polcyn, J., Turczak, A. (2018). Similarity of the European Union countries in terms of graduates' fields of education. European Journal of Service Management, 2 (26), 199-207. DOI: 10.18276/ejsm.2018.26-25. 